DOI https://doi.org/10.30525/978-9934-26-004-9-111

\title{
ВИКОРИСТАННЯ ПРОСТОРУ В ДИЗАЙНІ ДОПОВНЕНОЇ РЕАЛЬНОСТІ ДЛЯ ТВОРІВ ЖИВОПИСУ ТА ГРАФІКИ
}

\author{
Опалєв М. Л. \\ доиент, \\ в.о. завідувача кафедри мультимедійного дизайну \\ Фоміна К. О. \\ аспірант кафедри мультимедійного дизайну \\ Харківської державної академії дизайну і мистеитв \\ м. Харків, Україна
}

Звичні художні твори різних технік, пізнаваності та стилів 3 розповсюдженням технологій доповненої i змішаної реальності набувають нових якостей. Картини, плакати, малюнки, настінні розписи, графіті, книжкові ілюстрації та ще багато різноманітних за сферами використання об'єктів приміряють на себе нові можливості. В даній роботі розглядаються види простору та особливості його використання в дизайні доповненої реальності (англ. Augmented Reality, далі - AR). AR дає змогу накладати на зображення декілька різних за призначенням шарів інформації (інформаційний, керуючий, об'єктний тощо). Розглянемо випадки, коли дизайн $\mathrm{AR}$ відповідає за «доповнення» об'єктного шару - візуальної складової твору. Під твором розуміємо певний живопис чи графіку.

Кожний візуальний твір, що знаходиться у предметному світі, має свої обмеження. По-перше, фізичні параметри: форму, матеріал та розміри. По-друге, необхідність імітації глибини простору (перспективи) на пласкій поверхні. По-третє, передачу лише певного моменту в часі. В залежності від твору, другий i третій компоненти можуть бути неявними в силу статичності зображення та стилістики і проявляться лише під час анімації. Одна з особливостей дизайну $\mathrm{AR}$ - використання простору таким способом, який не досяжний для зображень на площині. Застосування цифрового простору є однією 3 переваг використання доповненої реальності з творами образотворчого мистецтва, зокрема живописом та графікою. Розглянемо способи використання простору в дизайні AR.

Певні передумови для варіантів застосування уважний глядач може знайти в роботах мультиплікаторів, зокрема в мультфільмах Діснею, або 
інших фільмах, де автори фантазують на тему реальності. Наприклад, персонажі Діснею нерідко стрибають у картини, що висять на стінах, або вистрибують 3 них [1]; з картинами які розмовляють або оживають можна зустрітись в фільмах про Гарі Поттера [2] та багатьох інших тощо. Ми виділяємо чотири види використання простору в дизайні доповненої реальності.

У межах плаского твору $(x, y)$. Дії та анімації відбуваються в межах формату та розмірів. Таким чином всі об'єкти, що виходять за межі площини твору - зникають. У проекті з AR студентів ХДАДМ [3] (кафедра «Мультимедійний дизайн») «ожили» фігури на фризі будівлі COAC (El Collegi d'Arquitectes de Catalunya, Placa Nova, Barcelona). Будівля прикрашена серією піщано-литих фризів Пікассо, виготовленими скандинавським художником Карлом Нешаром (Carl Nesjar). Фігури «Фризу Гігантів» на фасаді Нової Площі отримали тривимірність. Вони виринають з площини бетонного фасаду, виконують певні рухи та занурюються в площину. Фігури похитують гілками, палками, трохи повертають свої тіла та погойдуються. «Дитячий фриз» на фасаді вулиці Carrer dels Arcs отримав стрімку анімацію, де процесія фігур, що танцюють, переміщується з правого боку фризу до лівого. Кожна 3 них виконує певні рухи тілом: хитає руками, рухає ногами, вертить головою, стукає в тарілки, грає на трубі тощо. Безкінечний рух триває по колу і всі дієві особи, що виринають з правого боку фризу, зникають за межами лівого.

Buxid за межі $(x, y)$. Дія може виходити за межі твору та продовжуватись у координатній площині картини. Об'єкти, що перетинають межі, можуть залишатись видимими та продовжувати свої дії в межах резервного простору навколо нього. Ще до доповненої реальності художники та дизайнери намагались вийти за межі своєї роботи та використовували для цього різні прийоми. У фізичному світі таким експериментам стають на заваді проблеми матеріалу, ваги, розмірів та монтажу таких об'єктів, а в цифровому - реальні розміри цифрового продукту (справжня ширина то висота відео, розмір екрану тощо). Доповнена реальність дозволяє обійти деякі з цих обмежень та втілити те, що важко влаштувати в реальності. В проектній пропозиції дизайнерів кафедри МД для виставки плакатів «4-го блоку» в серії графічних робіт були розроблені анімації, які задіюють простір навколо основної графіки. В роботі «Дерево» українського графіка Ільдана Яхіна з дерева облітають листки, тріпочуть крила комах, дивні тіні з'являються i зникають на стовбурі. Добре підібрана техніка анімації, іiі вид та прийоми органічно вплетені в ілюстрацію. Об'єкти вилітають 3 площини 
роботи за їі межі та кружляють навкруги на фоні паспарту (в координатних межах роботи) [4]. У роботі цього ж автора «Останній лист» павутиння, що накриває картину, а також крильця комах теж виступають за межі зображення, а світлові бліки підсвічують частини зображення.

Внутрішній простір ( $x, y,-z)$. В межах твору враховуються характеристики його глибини і об'єкти, які його наповнюють, відповідно модифікуються та трансформуються. На них може впливати фокусна відстань, колірні зміни. Може бути розроблена повноцінна тривимірна сцена, що дозволяє «зазирнути» в середину картини, також можуть використовуватись ефект розбиття зображення на плани та імітація театральних куліс. Глибина у внутрішньому просторі уявна. В залежності від того, що зображено - імітована відстань може варіюватись від сантиметрів до сотень кілометрів. Дизайн-студія «Frog» iз Сан-Франциско розробила проект для ретроспективи сюрреаліста Рене Магрітта, роботи якого знаходяться в Музеї сучасного мистецтва цього міста. В галереї знаходиться шість «вікон», кожне 3 яких містить елементи справжніх картин Магрітта. Конструкції включають також камери зондування глибини та технологію відстеження руху. Поки глядачі оглядають вікна, їх відображення може змінюватися, зображення або предмети у вікнах можуть рухатися. Ця парадоксальна i провокативна виставка відкриває шлюз у цифрову реальність і глядачі стають частиною того, що зображено у вікнах [5].

Зовнішній, навколишній простір $(x, y,+z)$. Можливість виходу за межі картини не лише в іiі координатній площині, а й 3 використанням перпендикулярної осі. Зображення/об'єкти можуть видаватись вперед, виходити у простір глядача. Уявлення про глибину в навколишньому просторі співпадають із реальністю та обмежені фізичними параметрами цього середовища. Дизайнер має враховувати відстань та можливий вільний простір навколо твору, адже об'єкти у навколишньому просторі будуть оцінені за розмірами, що відповідають реальному світу і спроби показати величезні відстані, які не відповідають реальності будуть відчуватись лише як масштабовані. Проте, об'єкти в цьому просторі можна роздивитись $з$ різних сторін. А от для створення ефекту глибини та величезної відстані буде необхідно знову занурити об'єкт у нову площину, яка буде імітувати новий фрагмент реальності - тобто знову перейти на рівень внутрішнього простору.

В процесі створення кінцевого продукту - дизайну доповненої реальності, дизайнер може комбінувати всі чотири типи просторів в залежності від потреб. Для демонстрації польоту метелика у доповненій 
реальності, що вирвався з площини картини у реальність - достатньо середовища, повітря, що навколо. А для демонстрації, наприклад, пірнання риби, що винирнула з площини картини та пірнула у реальну підлогу, необхідно вже додати уявну площину, в яку вона зануриться i враховувати іiі в дизайні. Площина може бути не видимою для глядача, або видимою, але вона має існувати. Ми також пропонуємо принцип мультиплощин (multiplanes) - коли поряд із основним твором у просторі розміщуються інші, віртуальні площини, що можуть використовувались як розширення існуючого простору, надання йому додаткових глибин, таких собі «порталів». Уявна риба таким чином не просто зникає при контакті з підлогою, а занурюється в неї, поступово віддаляючись від глядача. Такий ефект досягається імітацією глибини на поверхні площини, адже ми не можемо насправді побачити те, що знаходиться під підлогою. Інший прийом з використанням мультиплощин - коли поряд 3 основною площиною картини розміщуються й інші - де знаходяться подібні їй копії або інші твори, такої ж, або відмінної форми. Дія в них може відбуватись одночасно $з$ діями в основному творі або поступово переходити від однієї площини до іншої. В таких площинах можуть бути варіації на один сюжет або цілком самостійні сценарії.

Отже, в дизайні доповненої реальності простір може бути задіяний як у геометричних межах твору так і виходити за них. Для передачі відчуття глибини може бути задіяний внутрішній простір твору або зовнішній, що знаходиться навколо, в реальному середовищі, де розміщений твір. Анімація, що доповнює твір, може бути в межах поточної сцени, або представляти собою серію сцен, що змінюють одна одну. Нами було запропоновано термін «мультиплощини», коли дизайнери використовують не лише основну площину твору та повітря навколо, а й створюють навколо та розміщують у просторі додаткові площини для формування просторів різної глибини.

\section{Література:}

1. Веселі мелодії. Золота колекція (1-6 сезон) [Електронний ресурс]: мультфільми. реж. Чак Джонс, Фриц Фрилинг, Роберт МакКимсон. Warner Bros. Cartoons, 2012. 3 електрон. опт. диски (DVD-ROM).

2. Гаррі Поттер і філософський камінь [Електронний ресурс]: фільм. реж. Кріс Коламбус. Warner Bros, 2001. 1 електрон. опт. диск (DVD-ROM).

3. Експеримент із доповненої реальності в центрі Барселони, 2020 p. Кер. Опалєв М. Л. URL: https://youtu.be/x7NmQv6s20Y (дата звернення 20.11.2020) 
4. Доповнена реальність до графічних робіт із колекції музею «4-й Блок». кер. Опалєв М. Л. URL: https://www.youtube.com/watch?v= 7CQzCHsg_SM (дата звернення 20.11.2020)

5. Augmenting Fine Art with SFMOMA (The San Francisco Museum of Modern Art). Special exhibition, "Rene Magritte: The Fifth Season,”. 2018. URL: https://www.youtube.com/watch?v=Oih_StvytQs (дата звернення 17.11.2020)

DOI https://doi.org/10.30525/978-9934-26-004-9-112

\title{
ДИТЯЧА ТВОРЧІСТЬ У ДИЗАЙНІ УКРАЇНСЬКОЇ КНИГИ
}

\author{
Пшінка Н. М. \\ аспірант, викладач кафедри рисунка та живопису \\ Київського національного університету технологій та дизайну \\ Гула Є. П. \\ професор, \\ завідувач кафедри рисунка та живопису \\ Київського наиіонального університету технологій та дизайну \\ м. Київ, Украӥна
}

Дитячі малюнки у книжкових виданнях минулого століття використовувалися зрідка, оскільки юні митці здатні відтворити власні емоції, свій внутрішній світ, але від них не можна очікувати цілісного бачення архітектоніки книги як єдиного організму, проєктування стрункого, продуманого макету тощо, а тому необхідним є залучення професійного дизайнера, який, втім, також був обмежений технічними можливостями тогочасної поліграфії. I лише із появою і розвитком цифрових комп'ютерних технологій стало можливим ширше залучення дітей до ілюстрування книжок.

Вже $з$ 1990-х у Національному видавництві дитячої літератури «Веселка» розпочинається активний пошук нових форм подачі візуального матеріалу. Видавництво організовує конкурси, підтримує зв'язок із дитячими студіями і школами мистецтв, започатковує серію «Ластовенятко», де й друкуються юні таланти. Для нашого дослідження цікаві насамперед ті серійні видання, де i авторами текстів, i художниками-ілюстраторами виступають діти $[1,2,3,4]$. 